\title{
Application of Morphological Indices in the Assessment of Type and Function in Sheep
}

\author{
Aplicación de Índices Morfológicos en la Evaluación de Tipo y Función en Oveja
}

\author{
A. E. Salako
}

SALAKO, A. E. Application of morphological indices in the assessment of type and function in sheep. Int. J. Morphol., 24(1):13-18, 2006.

SUMMARY: Live weight and eight body measurements records taken on 284 sheep comprising 226 West African Dwarf and 58 Yankasa sheep were analysed. The sheep were extensively managed within the south west Nigeria. The aim was to achieve a preliminary assessment of type and function from zoometrical indices produced from combinations of different morphometric scores. The indices used were weight, height slope, length index, width slope, depth index, foreleg length balance and cumulative index. The body measurements used were wither height, body length, hip length, hip width, rump height, foreleg length, chest width and heart girth.

The body measurements showed that the Yankasa is bigger than the WAD sheep. The measured parts are highly correlated. Tested indices showed that both sheep are typical meat animals. This was shown by the cumulative index, length and balance indices which were 2.80, 1.01 and 0.59 in WAD and 1.18, 0.93 and 0.75 for Yankasa respectively. The distribution of the indices among the different age groups revealed that weight index is highest at the 8-tooth age for both breeds, this trend is the same for length index, foreleg length index and cumulative indices. The respective coefficient of variation between breeds indicates the amount of opportunity available for improving the breeds through selection. Further, height slope index/length index and weight index and height slope/cumulative index were significantly $(\mathrm{p}<0.05)$ correlated. The implications for the respective varieties are discussed.

KEY WORDS: Indices; Indigenous sheep; Body measurements; Function.

\section{INTRODUCTION}

The assessment of the powers of body measurements in the estimation of weights and the accuracies of body weights in the estimation of size among livestock species has been widely reported. Body weight is the commonly reported measure of size (Fitzhugh \& Bradford, 1983). The reliability of single measurements such as wither height, body length, heart girth, rump height and width e.t.c. in the estimation of weight at both traditional and institutional levels have been widely documented. Others have even used cephalic dimensions as indicators of breed, origin and relationships within species (Jewel, 1963). EAAP and FAO have used wither height as a prime indicator of type in beef (Simon \& Buchanauer, 1993) because it indicates long bone growth. But sometimes, rump height has been preferred to wither height. Recently, both height at withers and rump have been considered limited in their values as indicators of weight and as having negligible value as indicators of type and function. Beyond just weights type and function as a better indicator of the usefulness of the animal is fast becoming more important. Ordinarily, even the value of weight itself is limited without some qualification and probably quantification of associated type and conformation. Alderson (1999) reported that single linear measurements are more relevant for on-farm within-herd use. This is probably because of the reported significant influence of husbandry system on certain body measurements. However, different combinations of the measurements will likely be more useful.

The ratios body weight/ wither height and round measurement / wither height has been proposed as an index of beef type (Knapp \& Cook, 1933; Gregory, 1933) and this was found by Guilbert \& Gregory (1952) to be highly correlated with grade in Hereford cattle.

Schwabe has used a more complex formula involving girth height and body length to describe weight (Schwabe \& 
Hall, 1989) and more recently, Alderson developed a system of linear measurements to provide an assessment of type in beef and overall value of an animal. This study was designed to test the same system for the assess type and function in two indigenous sheep of Nigeria-the WAD and Yankasa. This is considered most useful because it has a neutral correlation with age. Consequently, it will be useful as a measure in young animals to enable earlier assessment of breeding animals for selection and to predict mature rating. Indices are also considered a superior option for assessment of weight because it incorporates measures of desirable conformation, namely, length and balance (Alderson). It is expected to provide tested empirical alternative to the limited use of single measurements for the assessment of type, weight and function as well as enhance the ability of breeders to select potential breeding stock. It will provide potential purchasers with a reliable evaluation of animals since the measurements are associated with production characteristics. Desirable body conformation from the viewpoint of meat production is such a complex character that little progress has been made in reducing it to a single body measurement which can be taken on the live animal. Therefore body conformation score which is highly subjective and having low heritability have been widely used. But with the introduction of indices from body measurements, objective assessment of body conformation from the stand point of type may be relatively easier.

By type, it is meant the body form and structure which is supposed to be ideal for the purpose for which the animal is produced. It includes something more than just size and scale. Before now, type has been traditionally estimated by visual appraisal and not by ruler or tape. Type score (usually taken at weaning time) is useful in the selection of breeding stock because a visual appraisal is rather simple and because the price per kilogramme of feeder and slaughter animal is dependent to a considerable extent on this trait.

Alderson, who developed an index system for assessment of type and function in cattle, suggested the application of the system to other species. This investigation explores the possibility of extending the use of morphological indices beyond the on-farm within-herd comparisons, to determination of type and function between breeds within species.

\section{MATERIAL AND METHOD}

Eight different body measurements and live weight were taken on 284 sheep comprising 58 Yankasa and 226 WAD, belonging to four age groups: milk teeth, 4-tooth and 8 -tooth, the fourth group being adults above 21 months of age. They comprised rams and ewes that have been extensively managed. Body measurements taken on each animal were wither height, body length, hip length, hip width, rump height, foreleg length, chest width and heart girth. The reference points and procedure for the body measurement were as prescribed elsewhere in Salako \& Ngere (2002). Data were entered into a standard format, which was transferred to the computer for analysis as appropriate. Pregnant animals were avoided in sampling because of the effect pregnancy can produce on some body parameters especially thoracic measurements.

Statistical analysis. Mean (X), standard deviation (SD), and coefficient of variation (CV) were computed for each body measurement using the PROCMEANS procedure of the SAS (1989) package. This was done for each age and genetic group.

The following indices were calculated from the mean values of body measurements for each age group including the adult group, according to the method of Alderson:

Weight: Body length $\mathrm{x}$ girth depth $\mathrm{x}$ (hip width + chest width)/2) Height slope: Wither height - rump height

Length index: Body length/wither height

Width slope: Hip width/chest width

Depth index: Chest depth/ wither height

Foreleg length: Wither height - chest depth

Balance: (Rump length $\mathrm{x}$ hip width)/ (chest depth $\mathrm{x}$ Chest width) Cumulative index: (Weight /breed average weight) +length index+ balance

Correlation among the indices was also computed for each age group and breed.

\section{RESULTS}

Results were expressed as mean, standard deviation and coefficient of variation for each linear measurement.

The description of the sampled populations is presented in Table I. The Yankasa sheep had higher values than the WAD sheep considering live weight and all linear body measurements except the shoulder width $(17.06 \pm 2.43 \mathrm{~cm}$ against $15.08 \pm 1.22 \mathrm{~cm})$. There was a large disparity between the live weight of the two breeds, $25.03 \pm 5.21 \mathrm{~cm}$ for WAD and $41.60 \pm 6.47 \mathrm{~cm}$ for Yankasa. It indicates that the Yankasa sheep is genetically bigger than the WAD sheep although the significance of the difference between them was not tested. Both sheep stood higher at wither than rump, sloping backwards from the posterior. However, the difference between the heights (wither and 
Application of morphological indices in the assessment of type and function in sheep. Int. J. Morphol., 24(1):13-18, 2006

Table I. Mean, Standard deviation and coefficient of variation of body measurements of adult animals.

\begin{tabular}{lllllll}
\hline & \multicolumn{3}{c}{ WAD $(\mathrm{n}=226)$} & \multicolumn{3}{c}{ Yankasa (n=58) } \\
Body measurements $(\mathrm{cm})$ & $\mathrm{X}$ & $\mathrm{S} . \mathrm{D}$ & $\mathrm{CV}$ & $\mathrm{X}$ & SD & $\mathrm{CV}$ \\
\hline Live weight $(\mathrm{kg})$ & 25.03 & 5.21 & 0.21 & 41.6 & 6.47 & 0.16 \\
Withers height & 61.74 & 4.43 & 0.06 & 76.16 & 7.39 & 0.09 \\
Rump height & 59.20 & 4.59 & 0.08 & 72.57 & 4.14 & 0.06 \\
Body len gth & 62.56 & 5.60 & 0.08 & 70.9 & 5.67 & 0.08 \\
Foreleg length & 38.92 & 3.60 & 0.09 & 47.73 & 3.35 & 0.70 \\
Shoulder width & 17.06 & 2.43 & 0.14 & 15.08 & 1.22 & 0.08 \\
Rump width & 18.01 & 3.19 & 0.18 & 21.45 & 2.27 & 0.10 \\
Rump length & 16.99 & 4.15 & 0.24 & 21.29 & 2.04 & 0.09 \\
Heart girth & 72.94 & 10.16 & 0.14 & 86.63 & 6.93 & 0.80 \\
\hline
\end{tabular}

Table II: Correlation among body measurements of the adult group

\begin{tabular}{|c|c|c|c|c|c|c|c|c|c|}
\hline & \multicolumn{9}{|c|}{ WAD } \\
\hline & LW & WH & BL & FL & SW & RH & $\mathbf{R L}$ & RW & HG \\
\hline LW & & 0.72 & 0.67 & 0.66 & 0.43 & 0.67 & 0.69 & 0.56 & 0.81 \\
\hline WH & 0.78 & & 0.67 & 0.78 & 0.48 & 0.76 & 0.77 & 0.59 & 0.83 \\
\hline BL & 0.83 & 0.79 & & 0.79 & 0.50 & 0.76 & 0.83 & 0.73 & 0.79 \\
\hline FL & 0.64 & 0.77 & 0.70 & & 0.44 & 0.84 & 0.80 & 0.56 & 0.79 \\
\hline SW & 0.67 & 0.62 & 0.71 & 0.62 & & 0.56 & 0.48 & 0.29 & 0.61 \\
\hline RH & 0.70 & 0.77 & 0.74 & 0.72 & 0.58 & & 0.79 & 0.59 & 0.80 \\
\hline RL & 0.43 & 0.57 & 0.51 & 0.51 & 0.53 & 0.52 & & 0.80 & 0.82 \\
\hline RW & 0.79 & 0.69 & 0.73 & 0.55 & 0.52 & 0.54 & 0.23 & & 0.67 \\
\hline HG & 0.85 & 0.82 & 0.82 & 0.68 & 0.72 & 0.77 & 0.48 & 0.78 & \\
\hline & LW & WH & BL & FL & SW & RH & RL & RW & HG \\
\hline
\end{tabular}

rump) was not the same in both breeds being $2.54 \mathrm{~cm}$ in WAD and $3.49 \mathrm{~cm}$ in Yankasa. Considering body length in relation to wither height, the two measurements were closer in the WAD than in Yankasa, being $61.74 \pm 4.43$ for wither height and $62.56 \pm 5.60 \mathrm{~cm}$ for body length in WAD and $76.16 \pm 7.39$ and $70.90 \pm 5.67 \mathrm{~cm}$, respectively for Yankasa. Both breeds are shown to be taller than long although this is more apparent in the Yankasa than WAD. Foreleg length was $63.03 \%$ of wither height in WAD and $62.67 \%$ in Yankasa. Differences between Shoulder width and rump width in both breeds are considerable: $0.95 \mathrm{~cm}$ in WAD and $6.37 \mathrm{~cm}$ in Yankasa. The girths of both breeds were proportional to their size although the effect of gut-fill on the measurement might affect the accuracy of this comparison. This is suggested by the variability in the heart girth of WAD as shown by associated standard deviation (Table I).

Correlations analysis of the measured parameters showed strong association. Most variable pairs were significantly $(\mathrm{p}<0.05)$ and positively correlated. The upper and lower part of the matrix described the WAD and Yankasa, respectively (Table II). Wither height was correlated most closely with heart girth (0.83) in both WAD and Yankasa. This was closely followed by heart girth and foreleg length (0.79 and 0.77) respectively for WAD and Yankasa. However, both hip width and chest width had relatively lower correlations with weight $(0.56$ and 0.43$)$ respectively for WAD and 0.69 and 0.62 respectively for Yankasa. Heart girth/ chest depth had highest correlation with weight: 0.81 in both breeds. While rump width and chest width had very low correlation of 0.29 in WAD, it had 0.52 in Yankasa. These two measurements appear the point of differentiation between the two sheep. Correlation coefficient between wither height and rump height were high being 0.76 and 0.77 in WAD and Yankasa respectively. The association between body length and wither height was relatively lower for the WAD $(0.67$ against 0.79 in Yankasa. While the WAD sheep was longer than tall $(62.56 \mathrm{~cm}$ against $61.74 \mathrm{~cm})$ the Yankasa was taller than long than long $(76.10 \mathrm{~cm}$ against $70.9 \mathrm{~cm})$

For weight, length, depth and cumulative indices, WAD had higher figures while for others namely, height slope, width slope and balance, Yankasa had higher figures. The height slope index indicated that Yankasa slopes more to the posterior end than WAD at the back (point of withers to rump). Width slope showed that Yankasa in a narrower animal. The difference between hip width and shoulder width is higher in Yankasa. This might have contributed to the Yankasa having a higher balance. However, cumulative index which appears more important because it takes more parameters into consideration more than others is even higher in the WAD and it indicates the over all value of the animal. 
Indices calculated from body measurements are presented in Table III.

Table III. Morphological indices of matured sheep over 21 months of age.

$\begin{array}{lrr}\text { Indices } & \text { WAD } & \text { Yankasa } \\ \text { Weight } & 1248.29 & 1126.01 \\ \text { Height slope } & 2.54 & 3.59 \\ \text { Length index } & 1.01 & 0.93 \\ \text { Width slope } & 1.06 & 1.42 \\ \text { Depth index } & 0.53 & 0.52 \\ \text { Foreleg index } & 28.74 & 36.16 \\ \text { Balance } & 0.59 & 0.75 \\ \text { Cumulative index } & 2.80 & 1.18\end{array}$

Height slope index indicated that Yankasa is sloppier than the WAD breed. The length index showed that relative to height, WAD sheep is longer bodied than .The length index showed that relative to height, WAD sheep is longer bodied than Yankasa. Width slope index showed that Yankasa is relatively narrower at the fore quarter than the hind.

In Table IV, the trend of the indices across the age groups showed that only the height slope, weight, foreleg length index, balance and cumulative index showed higher values in Yankasa. Coefficient of variation associated with each of the indices across breeds showed values were similar across breeds for cumulative index, width slope and balance while variability was quite different for the rest indices.

Table IV. Calculated morphological indices by age groups.

\begin{tabular}{|c|c|c|c|c|c|c|c|c|c|}
\hline \multirow[b]{2}{*}{$\begin{array}{l}\text { Age } \\
\text { group }\end{array}$} & \multicolumn{9}{|c|}{ Morphological Indices } \\
\hline & Breed & Weight & $\begin{array}{l}\text { Height } \\
\text { slope }\end{array}$ & $\begin{array}{l}\text { Length } \\
\text { Index }\end{array}$ & $\begin{array}{l}\text { Width } \\
\text { slope }\end{array}$ & $\begin{array}{l}\text { Depth } \\
\text { Index }\end{array}$ & $\begin{array}{l}\text { Foreleg } \\
\text { length index }\end{array}$ & Balance & $\begin{array}{c}\text { Cumulative } \\
\text { index }\end{array}$ \\
\hline Milk & WAD & 504.21 & 0.64 & 0.93 & 0.86 & 0.42 & 29.27 & 0.62 & 1.96 \\
\hline teeth & Yankasa & 524.28 & 2.17 & 0.90 & 4.12 & 0.45 & 33.21 & 0.77 & 2.14 \\
\hline \multirow[t]{2}{*}{ 4-teeth } & WAD & 1188.25 & 2.58 & 1.03 & 0.87 & 0.51 & 28.28 & 0.66 & 2.43 \\
\hline & Yankasa & 1082.44 & 3.24 & 0.94 & 6.22 & 0.49 & 36.39 & 0.79 & 2.57 \\
\hline 8 -teeth & WAD & 1310.10 & 1.77 & 0.99 & 0.58 & 0.5 & 31.11 & 0.52 & 2.54 \\
\hline \multirow[t]{2}{*}{$\mathrm{X} \pm \mathrm{SD}$} & WAD & $1000.85 \pm 424$ & $1.66 \pm 0.97$ & $0.93 \pm 0.05$ & $0.77 \pm 0.16$ & $0.48 \pm 0.05$ & $29.55 \pm 1.43$ & $0.58 \pm 0.05$ & $2.31 \pm 0.31$ \\
\hline & Yankasa & $975.89 \pm 405$ & $3.32 \pm 1.20$ & $0.92 \pm 0.02$ & $5.25 \pm 1.10$ & $0.48 \pm 0.03$ & $36.62 \pm 3.53$ & $0.77 \pm 0.02$ & $2.50 \pm 0.34$ \\
\hline \multirow[t]{2}{*}{$\mathrm{CV} \%$} & WAD & 43.40 & 58.43 & 5.31 & 20.81 & 10.20 & 4.83 & 8.62 & 12.99 \\
\hline & Yankasa & 41.90 & 37.26 & 2.17 & 20.20 & 5.41 & 9.63 & 6.50 & 13.60 \\
\hline
\end{tabular}

Table V. Correlations among morphological indices.

$\begin{array}{lllllllll} & \text { WI } & \text { HS } & \text { LI } & \text { WSI } & \text { DI } & \text { FLI } & \text { B } & \text { CI } \\ \text { WI } & & 0.84 & 0.85 & -0.59 & 0.97 & 0.31 & -0.75 & 0.99^{*} \\ \text { HS } & 0.96 & & 1.00^{*} & -0.07 & 0.95 & -0.25 & -0.81 & 0.82^{*} \\ \text { LI } & 0.68 & 0.44 & & -0.08 & 0.95 & -0.24 & -0.30 & 0.83 \\ \text { WSI } & 0.77 & 0.56 & 0.99 & & -0.38 & -0.94 & 0.98 & -0.62 \\ \text { DI } & 0.99 * & 0.92 & 0.76 & 0.84 & & 0.07 & -0.58 & 0.96 \\ \text { FLI } & 0.96 & 1.00 * & 0.45 & 0.57 & 0.93 & & 0.92 & 0.00 \\ \text { B } & -0,10 & -0.38 & 0.66 & 0.55 & 0.00 & -0.38 & & -0.38 \\ \text { CI } & 0.94 & 0.99 * & 0.40 & 0.51 & 0.90 & 0.99 * & -0.43 & \end{array}$

\section{DISCUSSION}

The indices calculated from linear measurements of both breeds established norms for breed type. It showed that the WAD sheep is generally short legged and longer bodied though smaller than Yankasa. Both breeds have the proportions of beef animals. Further, these indices suggested that when body proportions and the contributions of body length, girth depth, hip width and chest width are considered, the WAD is heavier than Yankasa. It is suggested that though any of these single measurements could well predict live weight accurately (this lends support to the traditional use of hip width as an indicator of live weight and meatiness in meat livestock) the combination was more reliable because of its neutral correlation with age (Tables III and IV). Height slope and length index showed the WAD sheep to be shorter but longer bodied than the Yankasa 1.66 $\pm 0.973,3.2 \pm 1.20$ and $0.93 \pm 0.05,0.92 \pm 0.02$ respectively (Table IV). Hall's (1991) suggestion that the WAD and Fulani sheep (to which Yankasa sheep belong) of Nigeria being both taller than long are obviously inferior to Western meat livestock. Considering therefore that length and balance indices are important indicators of meat quantity in live animals, Alderson argued that cumulative index is superior to weight for measurement of overall value of an animal because it incorporates measures of desirable 
conformation, length and balance. This study suggests that the WAD is meatier than the Yankasa of comparable age and weight although Yankasa has a higher overall value because of size. However, since the index is complex, requiring five measurements, other single parameters that can be used are body length, hip width and chest depth. The width slope and length indices are useful parameters for estimating balance, and can be important in the assessment of functionality. The considerable difference between the width slopes indices of both breeds is related to both their type and functionality, the WAD being a typical dwarf, the width at the hip is a relatively lower multiple of that at the shoulder and higher in Yankasa where the leg is longer as indicated by higher foreleg length index. The relatively higher balance of the WAD sheep has implication on its conformation and therefore type.

The body form (type, structure or proportions) supposed to be ideal for the purpose for which the animal is produced. Theoretically, in sheep, it seems that type and performance (function) have low genetic correlation and as a result, they are likely to be inherited independently. It is an indication that the group of genes responsible for inheritance of 'type' is independent of those responsible for 'performance/function'. It suggests that the assessment of one will be independent of the other and the body measurements used to assess each of them will almost be mutually exclusive. From this investigation this may not be strictly so because of the significant phenotypic correlations between the body parts reported. Indices such as 'cumulative index' that includes body weight may provide sufficient attention to 'type'. This was higher in the WAD than in Yankasa. Performance on the other hand especially with regards to meat production can be assessed from body measurements such as chest width, hip width and chest depth that are less closely associated with bone growth. These indices include width slope, balance, depth index and cumulative index (which include balance) in that order. Of these, width slope and balance are higher in Yankasa while depth index and cumulative index are higher in WAD. This suggests the possible overlap between the polygenes responsible for inheritance of type and function. It may be in order to suggest that indices that are produced from measurements that are more closely associated with bone growth such as foreleg length, height slope and length index are more appropriate for assessment of type. Assessment of type using body measurements is more objective than those obtained by visual appraisal though both are still inferior to 'function' as criterion for selecting breeding stock. In line with the report of this study, Alderson reported that Cumulative index is the best measure of functional value of an animal but it requires five linear measurements. It has value in detailed studies and analyses of breeds of cattle but it is too complicated to operate on a routine herd basis suggesting that the measurement of hip width or rump length, ideally combined in a rump area index, can offer simpler alternatives.

Cumulative index considered suitable as an indicator of function in cattle, was considered as an indicator of both type and function but more important for function in sheep in this investigation. This probably unveils the over- lapping position of the strict separate body measurements which are important in the determination of the two characteristics (type and function). The difference could also provide species difference in the use of indices in the assessment of type and function. If cumulative index that includes weight and balance is important in the determination of functionality, we ca say therefore that functionality is influenced by the environment and are therefore of limited value in between-herd comparison.

The changes in indices across the age groups tested were similar for the two breeds. Cumulative index which increased as age advanced as shown In table IV further established consistent type throughout the life time of the animals. The similar CV \% suggests that variability were the same and opportunity to select for type, if possible, were equal for the sheep.

It is suggested for future investigations in this regard that linear measurements be related to production characteristics other than weight.

SALAKO, A. E. Aplicación de índices morfológicos en la evaluación de tipo y función en oveja. Int. J. Morphol., 24(1):13-18, 2006.

RESUMEN: Fueron medidos el peso en vivo y 8 parámetros del cuerpo, en 284 ovejas, siendo 226 enanas del Oeste Africano y 58 ovejas Yankasa. Las ovejas fueron obtenidas dentro del Sur Oeste de Nigeria. El objetivo fue lograr una valoración preliminar del tipo y función de índices zoométricos producto de combinaciones de diferentes valores morfométricos. Los índices usados fueron: Peso, altura inclinada, índice de longitud, anchura inclinada, índice de profundidad, longitud equilibrio pata delantera y balance e índice acumulado. Las medidas del cuerpo usadas fueron: altura, longitud del cuerpo, altura de la cadera, ancho de la cadera, altura de las ancas, longitud pata delantera, ancho del pecho y contorno del corazón.

Las medidas del cuerpo mostaron que que la oveja Yankasa es más grande la oveja WAD. Las partes medidas están altamente correlacionadas. Índices testeados mostraron que ambas ovejas son animales típicos de carne. Esto fue demostrado por el índice acumulado, longitud y equilibrio de los índices que fueron 2.80, 1.01 y 0.59 en WAD y 1.18, 0.93 y 0.75 en Yankasa, respectivamente. La distribución de los índices entre los diferentes grupos etarios reveló que el índice peso es más alto a la edad de 8 dientes, para ambas ovejas. Esta tendencia es la misma para índice de longitud, largo de pata delantera e índices acumulados. El coeficiente de variación respectivo entre ovejas indica la cantidad de evaluar oportunidades para seleccionar las ovejas a través de instructivos. Además, el índice de altura inclinada/índice de longitud y el índice de peso y altura inclinada/índice acumulado se correlacionaron significativamente $(\mathrm{p}<0.05)$. Fueron discutidas las implicancias para las variedades respectivas.

PALABRAS CLAVE: Índices; Ovejas autóctonas; Medidas corporales; Función. 


\section{REFERENCES}

Alderson, G. L. H. The development of a system of linear measurements to provide an assessment of type and function of beef cattle. AGRI, 25:45-55, 1999.

Fitzhugh, H. A. \& Bradford, G. E. Productivity of hair sheep and opportunity for improvement. In: Hair sheep of Western Africa and the Americas. A genetic resource for the tropics. Edt: Fitzhugh H. A. and G. E. Bradford, 1983. pp 23-52.

Gregory, P. W. The nature of size factor in domestic breeds of cattle. Genetics, 18:221, 1933.

Guilbert, H. R. \& Gregory, P. W. Some features of growth and development of Hereford cattle. J. Animal Sci., 11:3, 1952.

Hall, S. J. G.Body dimensions of Nigerian cattle, sheep and goats. Anim. Prod. 53(1): 61-9, 1991.

Jewel, P. A. Cattle from British archaeological sites: In A. E. Mourant and F.E. Zeuner (eds.). Man and Cattle, Royal Anthropological Institute, London, 1963.
Knapp, B. \& Cook, A. C. A comparison of body measurements of beef and dual-purpose cattle. Proc. Am. Soc. An. Prod., 25:77, 1933.

Salako, A. E. \& Ngere, L. O. Application of multifactorial discriminant analysis in the morphometric structural differentiation of West African Dwarf and Yankasa sheep in Southwest Nigeria. Nig. Journal of Anim. Prod. 29(2):168-70, 2002.

SAS Statistical Analytical System. Guide for personnel computers. Release 8.1. SAS Institute. Inc. Cary. Northern Carolina, USA.

Shwabe, A. E. \& Hall, S. J. G.Dystocia in nine British breeds of cattle and its relationships to the dimensions of the dam and calf. The veterinary record, 125:636-9, 1989.

Simon, D. L. \& Buchanauer, D. Genetic diversity of European Livestock breeds. Wageningen Pers, 1993.

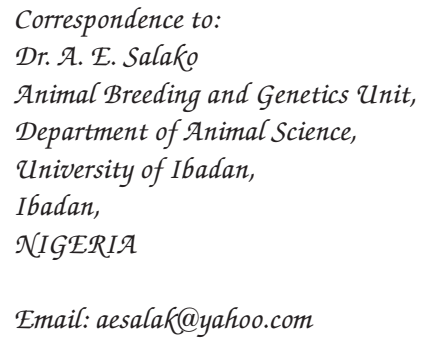

